\title{
Between the Topoi and Hope: On Ben Agger, Social Ontology, and Disciplinary Sociology
}

\author{
Mark P. Worrell
}

As a graduate student in the early 90s I spent many days rummaging through the library at the University of Kansas trying to get a handle on the world of Critical Social Theory. One author I repeatedly encountered was Ben Agger. I asked Bob Antonio about "this Ben Agger guy" who seemed to me to be doing pretty interesting work, and a lot of it, too. As my imaginary map of critical theory developed over time, Ben Agger was one of the "big time" figures who populated that constellation; and he always remained, for me, one of the "big time" theorists. Years later, after I had landed a tenure track job at SUNY Cortland, I submitted a paper on 'The Other Frankfurt School' to a session organized by Ben at the annual ASA meeting. I hoped for little more than a polite rejection but, surprisingly, not only was my paper accepted but it eventually became my entrée into the journal Fast Capitalism. Wow, I thought, somebody up there likes me. Over the years, about a half dozen of my articles were published in Fast Capitalism with Ben and Tim Luke at the helm and I ended up writing a couple of small books for Ben's Routledge series. The last book is notable because it was, basically, the one that marked his departure as editor from his own series and the way he left it says a lot about the generosity, loyalty and heterodox nature of Ben Agger's vision of intellectual community.

My little book on terrorism was a broad and critical examination of American foreign and domestic policy centered around terror as a kind of 'bow wave' generated by imperial motion. I liked the book, Ben was pleased, one reviewer thought it was just peachy, but another, one of those stuffed-shirt positivistic law and order types that the editor at Routledge selected to review the manuscript, was "horrified" and it looked like the book would be trashed on the basis of that single reaction. Ben fought intensely to get that book into print, and I gather the fight was somewhat brutal. Ultimately, Ben prevailed and as soon as Routledge capitulated, he resigned from his own series. He sent me two messages that day: your book will be published, and, about a minute later he sent another that said, by the way, I just resigned as editor. Obviously, I felt terrible over 'killing the series' — though it persists today under new editorship. I felt doubly bad because I know that while Ben might not literally wince in pain while reading my work, he could not have agreed with a lot of what I had to say. Indeed, I suspect that he viewed my whole theoretical project, synthesizing Marx with Durkheimian sociology with a degree of consternation — probably a great deal of consternation. My work toward a 'Marxheimian Sociology' could only look like a fool's errand to the vast and overwhelming majority of folks in the Critical Social Theory business, yet, that was Ben in a nutshell: supportive, generous and open-minded. His lack of dogmatism as well as his organizing energy made all the difference in my professional life and many scholars can say the same thing about the impact that Ben had on their careers and how he shaped their thinking. Ben Agger, in short, cultivated intellectual freedom, open-mindedness, and provided a space for a diverse group of scholars to stretch out and see what they could accomplish. And while many of us who circulate in and around Fast Capitalism will accomplish much in their scholarly lives, few will accomplish as much as Ben Agger did.

Ben's scholarly record is, by any measure, astonishing but what separates him from most other prolific writers was his knack for being years ahead of everybody else. For example, social ontology is all the rage at the moment, yet, at a time when virtually nobody had the foresight to tackle the problem, Ben was all over it. His 1989 book, 


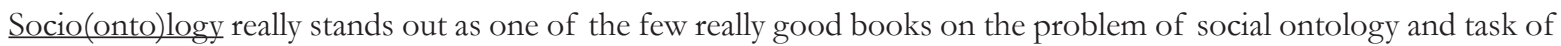
critical theory to demystify social facts. Not surprisingly, Durkheim came in for some severe criticism.

Evoking and thus provoking domination, sociology repeats Durkheim's dreary ontology; 'social facts' turn history into ontology. Freedom is equivalent to obedience; laws govern the advance of hierarchy, patriarchy, capital. Following Durkheim, sociology freezes powerless subjectivity into ontology, thus freezing it politically (1989: 6).

From this angle the Durkheimian program amounts to little more than a dogmatic narrowing of the discipline (1989: 71-102), submission to fate, and the valorization of obedience. Now, Ben is undeniably correct, Durkheim battled tirelessly to separate sociology from the nominalism of history and the reductionism of psychology. But obviously, the demands of the day were different than they are today — sociology would have withered or failed to emerge fully as a distinct way of thinking had Durkheim not fought to delimit it from the prevailing intellectual orthodoxy of his day.[1] One problem with this is the sacralization associated with separation and boundary formation. With sacralization one necessarily introduces taboo, insularity, and rigid inflexibility as well as the hypervaluation of one set of procedures (methods) over others. Once sociology had finally imbedded itself in the post-war monetary-quantoid-administrative system, and actually committed partial intellectual suicide, the way back to life was by liquidating the frozen reification of narrow disciplinary thinking that had abandoned conceptual thought for the lure of multivariate analyses. Be that as it may, let's go back to Durkheim's original intent when it came to sociology being a distinct field that had to focus on social facts of a completely different ontological status from other facts. [2]

'Fact' is derived from the Latin factum and the range of possible meanings includes "deed, action, event, occurrence, achievement, misdeed, real happening, result of doing, something done, in post-classical Latin [it is a] thing that has really occurred or is actually the case, thing known to be true ... use as noun of neuter past participle of facere to make" (Oxford English Dictionary). Facere is the shared root for both 'fact' and 'fetish.' A factum denotes not just an action or thing done but also an "evil deed" by a malefactor. A fact is not only believed to be real but is actually real; it is a thing that may preexist our individual existence but it is nonetheless made (manufactured) through concerted effort, a fact is a feat, in other words, with definite features, that normally lead across time and space to stupefaction on the part of makers and remakers, the eventual petrifaction (hardening or reification) of our creations, and, ultimately when the sun sets for any fact, the putrefaction or rotting of the thing and the degeneration into a putrid monstrosity. For sociology, the main point is that our creations (our social facts) are more than subjective or intersubjective realities, that they impose themselves upon us as authorities, and that to grasp their social nature we cannot reduce them down to smaller parts, nor, by contrast, project them behind the world, turning them into metaphysical entities. As the criminally-neglected neo-Hegelian philosopher Bernard Bosanquet says, if it is a fact, it is a force ([1923] 1965: 36). This is pure Durkheim: social facts and things are immaterial forces and collective passions that have material effects. Are we really willing or able to give up on a concept of social forces? Certainly, neither Marx nor contemporary critical sociology can do so while retaining coherence for no theory of value, the great subject-substance of the modern world, would be possible without a theory of force. If sociology is dedicated to the study of 'facts' are we then destined to perpetual servitude? Durkheim was, after all, fond of statements like "Liberty is the fruit of regulation" that so outraged many of his critics.

Even if the state, the commodity, or any other 'fact' is indeed an actual 'fact' 'it is no ultimate empirical datum, to be accepted and built into our world-picture willy-nilly. Its force has no claim on our approval merely because it exists: we prefer the attitude of Carlyle's Teufelsdröckh, holding these and all other facts in 'everlasting defiance' until we do approve them because we discover some value in them" (Hocking 1926: 74-75). Durkheim makes the same point in Suicide: the facticity of the social does not extinguish free will but actually proves its existence ([1897] 1951: 325). Durkheim would agree with Whitman, Sartre, Fromm, et al, that not only is one always free to disobey but one must disobey a great deal. Marx did not deny the facticity of the commodity but started from that premise and subjected the fact to withering, dialectical critique (of not only the commodity but simultaneously the established interpretive frameworks provided by classical political economy) to arrive at an objective sociological comprehension of the thing and a compelling judgment ([1867] 1976). There is no way beyond the commodity until we figure out what it is and the kind of force we are up against and there is something about that fact that resists revolutionary impulses.

Durkheim did share things in common with philosophical positivism, for example the principle that a whole possesses qualities that are different from those found in its parts, [3] but he rejected the notion that we are prohibited from obtaining objective knowledge of the substantial core of things. [4] We do not have to fear 'positive' knowledge 
because negation without a corresponding positivity is meaningless. Social facts, then, are not exactly fate. A theory of alienation is incomplete without a theory of reconciliation and while life is often an unhappy state of affairs and filled with evils, society is, in the final analysis, not only inescapable without embracing a degree of self-destruction (Hardimon 1994: 20) [5] but a "positive evil" that we should embrace even as we criticise it (Durkheim [1897] 1951: 212). While Durkheim clearly does have an ontology from our critical perspective and even though Ben's project was to demystify the social realm I find myself in the paradoxical situation of agreeing with both Durkheim's social ontology and Ben Agger's anti-ontology because they lead to the same thing: the de-reification of the social realm and social facts (see Durkheim [1912] 1995: 7). How can a card-carrying critical theorist hold such an apparently contradictory position? Ask yourself this: is the journal Fast Capitalism nothing but the sum total of words published over the years? Is it nothing more than the sum of the individuals that edit and publish the journal? Or, rather, is Fast Capitalism a sui generis project that is greater than and different than the sum of its parts? Being an 'organic' reality that is more than organized electricity does not mean that it is a transcendental Thing. We can, with Ben, reject dreary ontology while embracing Durkheim's concept of a social ontology. Fast Capitalism is objectively real and not reducible to anything less than the journal itself.

Normal sociology, subjectivist empirical and positive quantitative research, is pointless from the standpoint of the classical and critical traditions of investigating social facticities because these facts are forms of authority, they possess objective "dignity" (Adorno 1976: 72) and commercial sociology, oddly enough, does not have at its disposal a concept of authority while it claims to be authoritative. In sociology, there is no substance but merely subjective attitudes of equal value and magnitude. In other words, what sociology investigates today, and for the last several generations, is the abstracted person rather than society, institutions, forces, and individuated incarnations of those forces; the methods themselves are 'objective' but the findings and interpretations are incapable of pointing beyond abstracted subjectivism (Adorno 1976: 72). As Durkheim says, empiricism is irrational ([1912] 1995: 13) and we cannot use reified, irrational methods to comprehend the irrationality (the "dignity") of social facts. Here is where Ben Agger, Marx, critical theory, and Durkheim make a secret rendezvous: not at the worship of dignified and alien abstractions, submission to inhuman powers, and resignation to soul-crushing institutions, but the genuine 'cult' of the concrete individual creatively engaged in collective practice. It might seem odd to think about it this way, but Ben's career, devoted to critical theory as a calling, was, in many ways a fulfillment of the Durkheimian ethos — not to mention the obvious connection to Weber's reconciliation with the vocation or calling as an irrational necessity in the modern world.[6]

When Ben says, "As an employee of a state university who works in a sociology department, I am no more or less exempt from the general principle of capitalist administration — discipline — than workers on the automobile assembly line or office managers in large corporations" (1989: 305) that is true but not the whole story. Unfortunately, the boundary line separating the sausage factory and the university is somewhat blurred or even artificial (cf. Marx [1867] 1976: 644) and the vast majority of teachers are merely docile tools of the system (professionals) but some, and not an insignificant number, have an actual profession and profess a calling that, unlike the ordinary professional and "privileged hirelings of the state" (Weber 1946: 153) entails a transvaluation of values contrary to those created and enforced within the capitalist system. Not all employees of a big, capitalized institution are created equal and Ben clearly demonstrated this fact. In Weber's "Science as a Vocation" (1946) we see an explicit quantity-quality dialectic pointing a way toward something like vocational enjoyment within the cells of the state. The critical theorist has to start from their individual topos (the employee of an impersonal institution) to create "an alternative textural practice" that "makes way for a possible future" radically different from what exists (Agger 1989: 303). When your colleagues down the hall throw their hands up in the air when it comes to qualitative evaluations of your work, defeated at the base of the linguistic and conceptual wall, they have little choice but to retreat into the domain of numerical abstraction, count up your 'productivity', and get out of your way. This amounts to the 'magical' ability to defeat disciplinarians (here, again, Ben and Durkheim make another encounter) and simultaneously inspire others to engage in critical reasoning and theoretical improvisation.

Like the rest of us, Durkheim placed little faith in the state, the church, or the capitalist firm when it came to human salvation. His corporatism sounds anachronistic to our postmodern ears but the 'corporate' association that Durkheim had in mind is more aligned with the concept of what we might think of as the original intent of a 'soviet' (i.e., harmonious association or sovét, a democratic council) or a renovation of the medieval guild concept, than to what we think of as a capitalist-bureaucratic structure or the contradictory industrial labor unions of the postwar era. When I think of Fast Capitalism and the remarkable network of scholars that circulate around that sui generis social nucleus, I think Ben was putting into practice the kind of intense, periodic, and creative ritual life 
that Durkheim thought was one of the ways to solve the problem of life in the modern world. It might be an odd way of thinking of it, but Fast Capitalism provides a defined location within the larger social division of labor and functions as a mediating institution in the domain of critical thought and theory; the journal, to couch it in some Hegelianism, is a mediating particularity that connects individuals to the dimension of the organic and substantive heritage of social critique. Fast Capitalism is about to turn 12 years old and has had a better run than many critical writing collaborations have had. With Ben's passing I hoped the journal would find some way to press forward. I am pleased that all signs point to many more years of creativity with Tim Luke and David Arditi at the helm, carrying the vision of critical social theory and a community of alternative discourse forward for the next generation of social thinkers to participate in. In hindsight, it was inevitable I suppose. As an individual, Ben is no longer with us but his work and Fast Capitalism will survive for generations. Ben Agger is a social fact.

\section{Endnotes}

1. It's also worth pointing out that the surge in neoDurkheimian studies and the top-down reevaluation and reconstruction of Durkheim and his disciples was still years away. The disciplinary consensus regarding Durkheim was still dominated at that time by the odious connections to Parsonian functionalism and positivistic and scientistic sociology.

2. Durkheim explicitly rejects the idea that sociology leads to any ontology or ontologizing of whatever kind. The only active element in society are individuals but that society, collective consciousness and the system of material supports, is a distinct and sui generis form of 'external' thinking that cannot be explained by any other fact. Today, we would say that Durkheim, while rejecting philosophical ontology would be seen as a social ontologist. When we get 'behind' the symbols and rites, we find that it is durable and periodic association that is being enacted and symbolized.
3. Note, we are making a distinction between positive philosophy (the whole and the concrete) and positive science which is dedicated to the parts and the abstract (Bosanquet 1912: 33).

4. For more on classical positivism see Spaulding (1918: 248).

5. Somewhere Hegel says something near and dear to my heart right now about the parent dying in the child.

6. One might object to the preservation of the irrational in modern life but, first, the irrational is always rational from another point of view and, second, if we wish to continue enjoying things like art and music, then the irrational is inevitable (Weber 1958). Nothing would be more inhuman than purely rationalized music.

\section{References}

Adorno, T. W. 1976. "Sociology and Empirical Research." Pp. 68-86 in The Positivist Dispute in German Sociology by Theodor W. Adorno, Hans Albert, Ralf Dahrendorf, Jürgen Habermas, Harald Pilot, and Karl R. Popper. London: Heinemann.

Agger, Ben. 1989. Socio(onto)logy. Urbana: University of Illinois Press.

Bosanquet, Bernard. 1912. The Principle of Individuality and Value. London: Macmillan.

------. [1923] 1965. The Philosophical Theory of the State. New York: St Martin's.

Durkheim, Emile. [1897] 1951. Suicide, tr. by John A. Spaulding and George Simpson. New York: The Free Press.
- [1912] 1995. The Elementary Forms of Religious Life, tr. by Karen E. Fields. New York: Free Press.

Hardimon, Michael O. 1994. Hegel's Social Philosophy: The Project of Reconciliation. Cambridge: Cambridge University Press.

Hocking, William Ernest. 1926. Man and the State. New Haven: Yale University Press.

Marx, Karl. [1867] 1976. Capital: A Critique of Political Economy, Vol. 1, tr. by Ben Fowkes. New York: Penguin.

Spaulding, Edward Gleason. 1918. The New Rationalism. New York: Henry Holt. 
Weber, Max. 1946. From Max Weber: Essays in Sociology, ed. by Hans H. Gerth and C. Wright Mills. New York: Oxford University Press.

1958. The Rational and Social Foundations of Music. Carbondale: Southern Illinois University Press. 
